\title{
Correction to: Does prenatal surgical repair of myelomeningoceles lead to better school-age outcomes?
}

\author{
Faith Kim (D) David A. Bateman · Donna M. Garey
}

Published online: 20 May 2021

(C) The Author(s), under exclusive licence to Springer Nature America, Inc. 2021

Correction to: Journal of Perinatology

https://doi.org/10.1038/s41372-020-00903-9

Following online publication of this article, it was noticed that the citation to the original article was omitted. The citation is provided below. The original article has been corrected.
Manuscript citation: Houtrow AJ, Thom EA, Fletcher JM, Burrows PK, Adzick NS, Thomas NH, et al. Prenatal repair of myelomeningocele and school-age functional outcomes. Pediatrics 2020; 145: e20191544.

Publisher's Note Springer Nature remains neutral with regard to jurisdictional claims in published maps and institutional affiliations. 